\title{
Deterministic and Probabilistic Seismic Hazard Analysis in Province of DKI Jakarta (Case Study: Earthquakes' Data in Province of DKI Jakarta on January 1945 - December 2015)
}

\author{
Gebri Adinda ${ }^{1}$, RB. Fajriya Hakim ${ }^{2}$ \\ 1,2 Department of Statistics, Faculty of Mathematics and Science, Islamic University of Indonesia \\ 12611138@students.uii.ac.id, fajriyahakim@yahoo.com
}

\begin{abstract}
Seismic hazard analysis for Province of DKI Jakarta was conducted using Deterministic Seismic Hazard Analysis (DSHA) and Probabilistic Seismic Hazard Analysis (PSHA) method. The study used secondary data derived from the United States Geological Survey (USGS) at the time of observation on January 1945-December 2015. DSHA method was obtained the calculation of peak ground motion acceleration from Jakarta to return period of 50 years and 100 years. Furthermore, the method of PSHA was found the probability of exceeding the acceleration of ground motion in DKI Jakarta. The results show that DKI Jakarta is indicate as high category Marcelli scale which is more than 0.2 gals based on 44 points review in each district that has been taken. However, certain level of exceeding probability for any 44 points review is very small.
\end{abstract}

Keywords: Seismic Hazard; DKI Jakarta; DSHA; PSHA

\section{Introduction}

The damage of earthquake buildings is determined by several factors, which one is the earthquake strength and the environmental conditions where the building is constructed. The building damage in large scale can occur if the building does not meet seismic construction standards that could be impact on the usage of low-quality building materials. As a result, residents easily collapsed buildings hit by the earthquake. So, it is important to assert the appropriate standardization of earthquake-resistant buildings. To anticipate the occurrence of earthquakes in an area, it takes several studies of earthquake threat analysis in every disaster area. One disaster area in the provinces of Jakarta is the capital city of the Republic of Indonesia. DKI Jakarta is divided into five areas of the city administration and the administrative districts, namely: Administration Central Jakarta, East Jakarta, West Jakarta, South Jakarta, North Jakarta and the District administration of Seribu Islands. Based on Figure 1 and 2, among the six regions, East Jakarta has the largest total area of Jakarta by 28\% consist of 187.73 $\mathrm{km} 2$, second largest region, namely South Jakarta and North Jakarta by $22 \%$ that consist of $145,73 \mathrm{~km} 2$ and $142.20 \mathrm{~km} 2$ in South Jakarta to North Jakarta. Furthermore, the administrative area of West Jakarta is $19 \%$ of the total area of Jakarta $126.15 \mathrm{~km} 2$, Central Jakarta by $2 \%$ or $47.90 \mathrm{~km} 2$. Lastly, the smallest area occupied namely Seibu Islands only received $2 \%$ of the total area Prov. DKI Jakarta or amounted to $11.81 \mathrm{~km} 2$. Based on the fact, it is necessary to study related threat assessment to estimate the maximum acceleration of earthquake ground motion in DKI Jakarta and probabilities are exceeded to overcome losses caused by the disaster, one of them with study conduct disaster in Jakarta. This research can be used as reference for the government in disaster mitigation and earthquake-resistant buildings standardization determination in accordance with the maximum acceleration of ground motion in Jakarta. The method used is Deterministic Seismic Hazard Analysis (DSHA) and Probabilistic Seismic Hazard Analysis (PSHA). Based on the case described above, the problems can be formulated as follows.

1. How is the distribution of the seismic hazard in Jakarta?

2. How is the distribution of probability seismic hazard in Jakarta? 


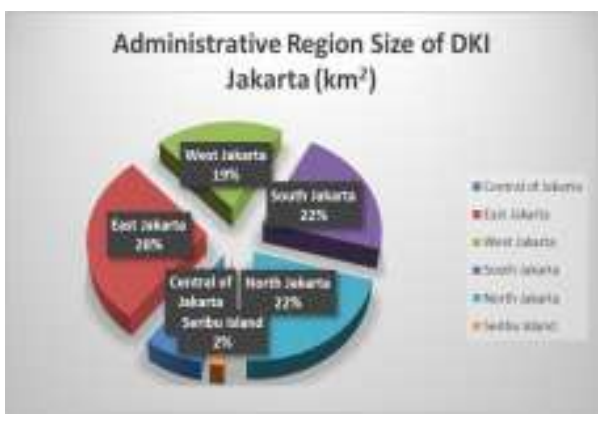

Fig. 1: Administrative Region Size of DKI Jakarta

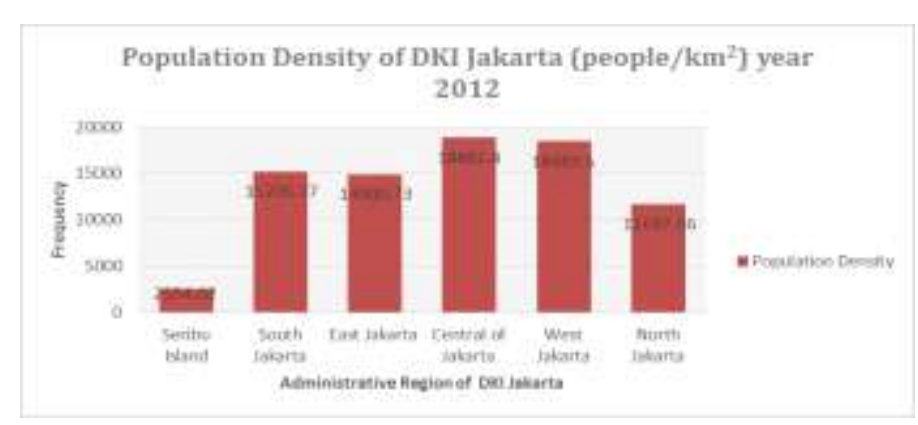

Fig. 2: Population Density of DKI Jakarta (people/km2) year 2012

\section{Related Works}

Several studies have to do modifications in used of methods DHSA and PSHA by adding Gumble Distribution, Attenuation Function and PGA (Peak Ground Acceleration) into the research. Lian-Fa Li, et al (2010) apply PSHA to make vulnerability model and make price of insurance risks to a disaster that was published in journal of "International Journal of Geographical Information Science" with titled "Using Spatial Analysis and Bayesian Network to Model the Vulnerability and Make Pricing of Catastrophic Risk". Hutapea and Mangape (2009) conducted a study that published in the Journal of Civil Engineering entitled "Analysis of Hazard and Ground Motion on Base Rock in city of Jakarta". This study used the total probability theory by using USGS-PSHA-07 for 3-dimensional modeling. In this experiment, the attenuation functions describe the relationship between ground motion intensity (I) and magnitude (M) and the distance (R) from a source of seismic point. Equations of attenuation used in this study are determined based on the mechanism of the source. Putra (2010) described the procedures for acquisition of PGA values at one of point in D.I. Yogyakarta on his research. PGA acquisition value using several methods, include of Gumble distribution and Probabilistic Seismic Hazard Analysis (PSHA) into a software system that has been integrated. Septianusa et al (2015) used DSHA and PSHA to measure PGA and exceedance probability of PGA in Bantul earthquakes. The result shows that Bantul included into category of earthquake danger with probability is above $15 \%$.

\section{Methodology}

Seismic hazard or risk analysis is analysis method to determine the probability of events per unit time from land movement (shaking) at a certain level that caused by earthquakes (McGuire, 2001). There are two methods for calculating Seismic Hazard Analysis, namely DSHA and PSHA.

\subsection{Deterministic Seismic Hazard Analysis (DSHA)}

DSHA generally applied to estimate the seismic acceleration for construction which is very dangerous in case of damage, such as building of Nuclear Power Station (PLTN) (Irsyam et al., 1999). The advantage of this method is easy to predict the seismic movements in the worst case scenario. The disadvantage of this method is not taking into consideration of probability in occurrence of earthquakes and influence of various uncertainties involved in the analysis (Kramer, 1996). This analysis started by developing a mathematical model that will be used to estimate the probability of earthquakes in the magnitude scale level or certain intensity on the interval period for a particular area. The result of DSHA is seismic design parameters, such as maximum acceleration and speed that can be exceeded for probability in return period.

\subsection{Probabilistic Seismic Hazard Analysis (PSHA)}

PSHA is deterministic analysis in various scenarios and also based not only on parameters of the earthquake that produced maximum ground motion. Thus, PSHA approach can use to predict how much the probability of the worst conditions will occur in the study area. This method makes it possible to take into account the influence of factors such as uncertainties in the analysis of the size, location and frequency of earthquakes. To find the exceedance probability by integration as follows. 


$$
P_{i}(\ln P G A>\ln \alpha)=\frac{1}{\sigma_{n} \sqrt{2 \pi}} \int_{\ln \alpha}^{\infty} \exp \left\{-\frac{\left[\ln \alpha-g\left(m_{i_{i}} d_{i}\right)\right]^{2}}{2 \sigma_{n}^{2}}\right\} d \ln P G A
$$

Then, add up all the scenarios of the earthquake source, to obtain an annual rate exceeding every lnPGA (0.2).

$R_{\text {tot }}(\ln P G A>\ln \alpha)=\sum_{i=1}^{n} R_{i}(\ln P G A>\ln \alpha)=\sum_{i=1}^{n} r_{i} P_{i}(\ln P G A>\ln \alpha)$

By using Poisson distribution, it can be calculated probability exceeded every ground in $\mathrm{T}$ years.

$P(\ln P G A>\ln \alpha \mid T)=1-\exp \left(-R_{\text {tot }} T\right)$

Whereas PGA is Peak Ground Acceleration, is mean of ln PGA, is standard deviation of lnPGA, is PGA return period in T year (gals) and I is 1, 2, 3, ..44 for the number of sub district in DKI Jakarta.

\section{Dataset}

Population observed in this study is all of subduction earthquakes occurred in Jakarta in a radius of $300 \mathrm{~km}$ from the point to review. The sample used in this study is a destructive earthquake with strength of greater than 5 Magnitude and depth of less than $500 \mathrm{~km}$ in the time range observed which is starting in January 1945 until December 2015. The kind of data is secondary data that provided by National Earthquake Information Center U.S. Geological Survey (USGS). The indicator for Table 1 is as the indicator of Class Earthquake Intensity (Oktariadi, 2009).

Time range : January 1945 - December 2015

The strength of earthquakes: 5.0 - 9.0 Magnitude

The depth of earthquakes : $0-500 \mathrm{~km}$

Point of review $\quad: \quad-6^{\circ} 21^{\prime} 15^{\prime \prime}$ LS dan $106^{\circ} 84^{\prime} 5$ BT; LS (Lat), BT(Long)

Outside circular radius $\quad: 300 \mathrm{~km}$

TABLE I: Indicator of Class Earthquake Intensity

\begin{tabular}{|c|c|c|c|}
\hline No & Class of earthquakes & Intensity (MMI) & Acceleration (Gals) \\
\hline 1 & Low & $<$ VI & $<0.15$ \\
\hline 2 & Moderate & VI-VII & $0.15-0.20$ \\
\hline 3 & High & $>$ VII & $>0.20$ \\
\hline
\end{tabular}

\section{Finding and Discussion}

\subsection{Descriptive Analysis of Seismic Record Data in DKI Jakarta}

Subduction earthquake caused by the subduction of the ocean and continental plates with a predetermined time range, of January 1945 until December 2015, obtained 395 records subduction earthquake that occurred in Prov. Jakarta within a period of 70 years.

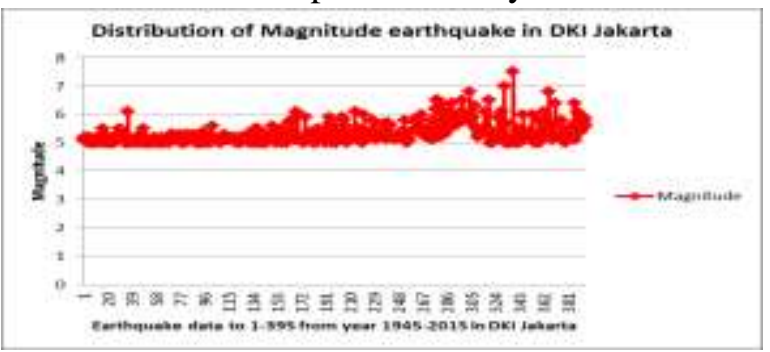

Fig. 3: Distribution of Earthquake Magnitude in DKI Jakarta

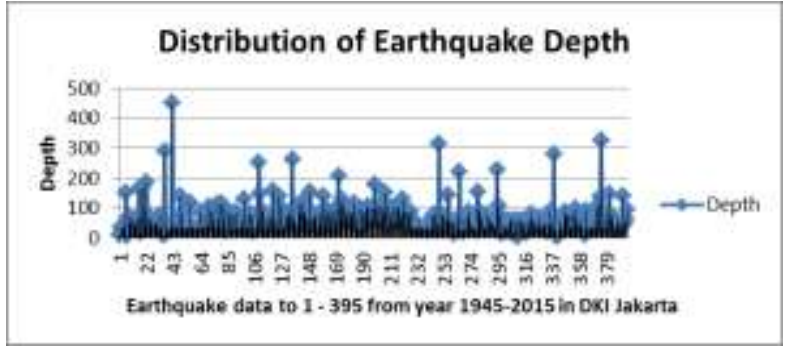

Fig. 4: Distribution of Earthquake Dept in DKI Jakarta

Based on Fig. 3 shows that the magnitude distribution of the earthquake occurred in Jakarta on the period of 70 years get 5-6 Mw or Richter scale. In the process of cleaning the data, it has been set that the data will be used in the study have magnitude earthquakes between 5.0 - 9.0 magnitude. However, during the period of 70 last years, Jakarta never experienced an earthquake that force exceeds 8.0 magnitudes. Based on Fig. 4 shows that during on period of 70 last year's DKI Jakarta experienced 395 earthquakes and occurred in 0-450 km of depth. In other words, there is no depth exceeding of $450 \mathrm{~km}$ in DKI Jakarta earthquake during the period 1945 up to 2015. Based 
on Figure 5., show that seismic event occurred in DKI Jakarta have depth to be around up to $100 \mathrm{~km}$ greater than up to $300 \mathrm{~km}$. However, magnitude was relatively large which has strength above 5.5 Richter scale than below 5.5 Richter scale

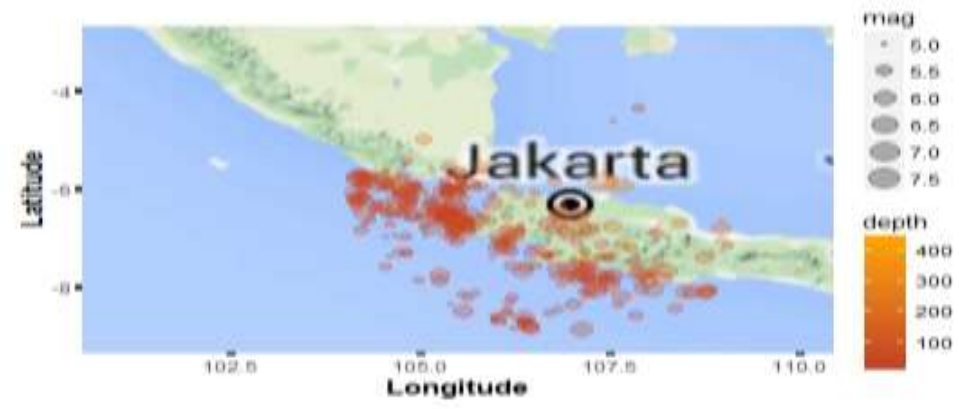

Fig. 5: Earthquakes Distribution of central point of DKI Jakarta (by using R Statistical Computing)

\subsection{DSHA and PSHA in DKI Jakarta}

\subsubsection{Peak Ground Acceleration (PGA) With Attenuation Function}

Attenuation function used to determine how much PGA value that was happened in an area or point of view. It depends on many aspects, such as natural conditions. Irsyam, et al (2010) said that attenuation function based on the similarities of geological and tectonic conditions of the area where the attenuation function is used. The data that used in this study based in record of earthquake data in the past with consider latitude, longitude and magnitude of the earthquake. Nowadays, unit of earthquake magnitude has conversion rule from Mw (Magnitude wave) or Richter scale. So, Table 3, shows that the first step on this study that made conversion in unit of earthquake magnitude into Magnitude wave $(\mathrm{Mw})$.

TABLE II: Conversion unit of earthquake magnitude to Mw

\begin{tabular}{|c|c|c|c|c|c|c|}
\hline Time & Lat & Long & Depth & Mag & MagType & $\begin{array}{l}\text { Conversio } \\
n\end{array}$ \\
\hline 1949-06-24 & $-6,381$ & 105,449 & 60 & 6,3 & $\mathrm{mw}$ & 6,3 \\
\hline 1951-10-14 & $-7,616$ & 106,823 & 55 & 5,9 & $\mathrm{mw}$ & 5,9 \\
\hline$\ldots$ & $\ldots$ & $\ldots$ & $\ldots$ & $\ldots$ & $\ldots$ & $\ldots$ \\
\hline $2015-11-28$ & $-6,9504$ & 106,0175 & 50,52 & 5,4 & mww & 5,4 \\
\hline $2015-12-19$ & $-8,3521$ & 107,0416 & 27 & 5,5 & mwb & 5,5 \\
\hline
\end{tabular}

TABLE III: Conversion of earthquake unit

\begin{tabular}{|l|}
\hline \multicolumn{1}{|c|}{ Conversion Correlation } \\
\hline$M_{W}=0.143 M_{s}^{2}-1.051 M_{s}+7.285$ \\
\hline$M_{W}=0,114 M_{b}^{2}-0,556 M_{b}+5,560$ \\
\hline$M_{W}=0,787 M_{E}-1,537$ \\
\hline$M_{b}=0,125 M_{L}^{2}-0,389 M_{L}+3,513$ \\
\hline$M_{L}=0,717 M_{D}+1,003$ \\
\hline
\end{tabular}

(Source: Asrurifak, 2010) Where: ML= Magnitude Local ; Mb= Magnitude Body; Mw= Magnitude Wave

The second step is obtained value of the conversion of units of the earthquake, and then computes the value of PGA of each earthquake. With the point of reviewing every district in Prov. Jakarta acquired by Google Maps earned a point reviewing a total of 44 sub-districts in Jakarta. Before that, it did transformation longitude and latitude values at each seismic data by using the function radians in Ms. Excel. This is done because the earth is considered a circle. So, it is necessary to do transformation into radians.

Next, calculate the value using the equation PGA attenuation function. Jakarta is the area with form of land (soil) and the source of the earthquake that is used only subduction earthquake then used the attenuation function of Young et al (1997). To obtain the value of the attenuation function, it is necessary to point review the epicenter value ( $r$ ). Calculating $r$ of the size of the earth is very difficult to do, so this calculation using equation by 
developed Asrurifak (2014) assuming the circular shape of the earth so that it makes in estimating the value of $r$. According to the explanation before, it has done transformation into radians to longitude and latitude.

TABLE IV: Value of Distance Epicenter to Point Review (Gambir District)

\begin{tabular}{|c|c|c|c|c|c|c|c|}
\hline \multirow{2}{*}{ No. } & \multirow{2}{*}{ Let } & \multirow{2}{*}{ Long } & \multirow{2}{*}{ Depth } & \multirow{2}{*}{$\begin{array}{c}\text { Mag } \\
\text { Yanovers }\end{array}$} & \multicolumn{2}{|c|}{ Point coordinstes in Circles } & \multirow{2}{*}{$\begin{array}{l}\text { Epiceptec } \\
\text { (r) kmm }\end{array}$} \\
\hline & & & & & Badian lat & Badian_lang & \\
\hline 1 & -6.7492 & 105.0498 & 10 & 5.60994 & -0.117799762 & 1.833447439 & 204.1003 \\
\hline 2 & -3.0495 & 107,4009 & 35 & 5.79136 & -0.14047497 & 1.874499325 & 219.2491 \\
\hline 3 & -5.6539 & 104.3352 & 35 & 5.69954 & -0.115123432 & 1.820992756 & 277.391 \\
\hline 4 & -6.1192 & 105.3524 & 43.17 & 5.79136 & -0.106900188 & 1.839920738 & 199.2196 \\
\hline$\ldots$ & ב. & & - & - & $\cdots$ & - & - \\
\hline 393 & -7.692 & 105.371 & 90 & 5.9 & -0.134290725 & 1.895924179 & 179.7776 \\
\hline 394 & -5.81 & 105.497 & 62.7 & 5.8 & -0.118996922 & 1.840971859 & 154.6733 \\
\hline 395 & -8.081 & 108.477 & 95.4 & 5.5 & -0.141040097 & 1.893200813 & 281.9492 \\
\hline
\end{tabular}

TABLE V: Value of PGA every incident Earthquake in Gambir

\begin{tabular}{|r|r|r|r|r|r|r|}
\hline No. & Epicenter (r) & Depth (d) & Hypocenter (H) & \multicolumn{1}{l|}{ Zt } & \multicolumn{1}{l}{$\ln ($ PGA) } & PGA \\
\hline 1 & 204.1003 & 10 & 204,3451148 & 0 & $-3,95158$ & 0,019224 \\
\hline 2 & 219.2491 & 35 & 222,0251449 & 0 & $-3,90457$ & 0,02015 \\
\hline$\ldots$ & $\ldots$ & $\ldots$ & $\ldots$ & $\ldots$ & $\ldots$ & $\ldots$ \\
\hline 394 & 164.6733 & 62,7 & 176,2061182 & 1 & $-3,202157479$ & 0,040674 \\
\hline 395 & 281.9492 & 95,4 & 297,651676 & 1 & $-3,737098291$ & 0,023823 \\
\hline
\end{tabular}

After the PGA values obtained from the lnPGA, found parameter value Gumble I. To determine the value of the parameter Gumble I, it took the value of $\mathrm{M}, \mathrm{A}, \mathrm{B}, \alpha$ and $\beta$. The value of the parameter $\alpha$ described the location and value of the scale parameter $\beta$ explained. Having obtained the value of $\alpha$ and $\beta$ then calculated the value of PGA at $T$ in the denoted with (a). This research looks at the value of re-period for 50 years and the next 100 years. To find the value of a, namely ground motion acceleration (PGA) in $\mathrm{T}$ years, used the equation (9) obtained the results, as the following table 6.

TABLE VI: The Value of Re-period on Ground Acceleration for Gambir District

\begin{tabular}{|c|c|c|c|c|c|}
\hline Return Period & A & B & $\boldsymbol{\alpha}$ & $\boldsymbol{\beta}$ & $\mathbf{a}$ \\
\hline 50 Years & $-0,06829$ & $-11,5528$ & 0,93399 & 11,55281 & 0,33271 \\
\hline 100 years & $-0,06829$ & $-11,5528$ & 0,93399 & 11,55281 & 0,392708 \\
\hline
\end{tabular}

From table 6 , A and B values obtained through the stages of regression that do that will generate value for $\alpha$ and $\beta$. A is the value of the intercept and $B$ is the value of the variable $X$. From the regression calculation can be found the value of $\alpha$ and $\beta$, then ground motion acceleration values obtained for the return period of 50 years by 0.33 gals and 100 years by 0.39 gals. Based on the class indicator earthquake intensity scale of Marcelli that the ground acceleration up to 0.2 including into high-class disaster. In the intensity (MMI) $>$ VII which means that if shocks, hence building a strong foundation that is not going to be heavily damaged.

\subsubsection{Calculation of Probability (PSHA)}

After getting the value of the acceleration of land for 50 years and 100 years, and then estimate the probability value of ground acceleration at 50 years and 100 years was exceeded, it to do for anticipate the ground acceleration will appear larger than in the previous forecast. Can be seen in the results of the previous calculation that the ground motion acceleration value to Gambir of 0.33 gals for a return period of 50 years and 0.39 gals to return period of 100 years into the high-class disaster. So that should be the calculation of the probability of when the acceleration value of land for each district in Jakarta. To estimate the probability of the value of ground acceleration at 50 years and 100 years is exceeded or not that has been conducted by Li et al (2010). On calculation of these estimates takes the estimated value of each earthquake opportunities in districts $T$ year exceeded by using equations 10 and 11 with the results presented in table 7.

TABLE VII: Probability Exceeded All Events Earthquake in Gambir

\begin{tabular}{|c|c|c|}
\hline $\mathbf{T}$ & $\boldsymbol{\alpha}$ & $\mathbf{P}(\mathbf{L n P G A}>\mathbf{L n}(\mathbf{a}))$ \\
\hline Year 50 & 0.33271 & 0.105521 \\
\hline Year 100 & 0.392708 & 0.045905 \\
\hline
\end{tabular}

TABLE VIII: PGA Value per District in DKI Jakarta 


\begin{tabular}{|c|c|c|c|c|c|c|c|c|c|}
\hline \multirow[t]{2}{*}{ No. } & \multirow[t]{2}{*}{ District } & \multirow[t]{2}{*}{ A } & \multirow[t]{2}{*}{ B } & \multirow[t]{2}{*}{$\alpha$} & \multirow[t]{2}{*}{$\beta$} & \multicolumn{2}{|c|}{$\begin{array}{l}\text { The relationship between } \\
\text { Return Period }(T) \text { and } \\
\text { Acceleration (a) in gals unit }\end{array}$} & \multicolumn{2}{|c|}{$\begin{array}{c}\text { Protuabilities Exceeded (Gals) in } \\
\text { year } T\end{array}$} \\
\hline & & & & & & $\begin{array}{l}\text { a u/ } 50 \\
\text { years }\end{array}$ & $\begin{array}{l}\text { a } / 100 \\
\text { years }\end{array}$ & 50 years & 100 years \\
\hline 1 & Gambir & $=0.06829$ & -11.5528 & 0.93399 & 11.55281 & 0.33270969 & 0.392707816 & 0.105521328 & 0.045905076 \\
\hline 2 & Tanah Abang & -0.05217 & -11.7538 & 0.949171 & 11.75384 & 0.32839124 & 0.387363239 & 0.127375208 & 0.056964656 \\
\hline. & $\ldots$ & $\ldots$ & $\ldots$ & in & $\ldots$ & in & $m$ & $=$ & $\ldots$ \\
\hline 44 & $\begin{array}{l}\text { Kep. Seribu } \\
\text { Selatan }\end{array}$ & 0.053259 & -15.5826 & 1.054703 & 15.58257 & 0.25446901 & 0.298951213 & 0.190423956 & 0.086711585 \\
\hline
\end{tabular}

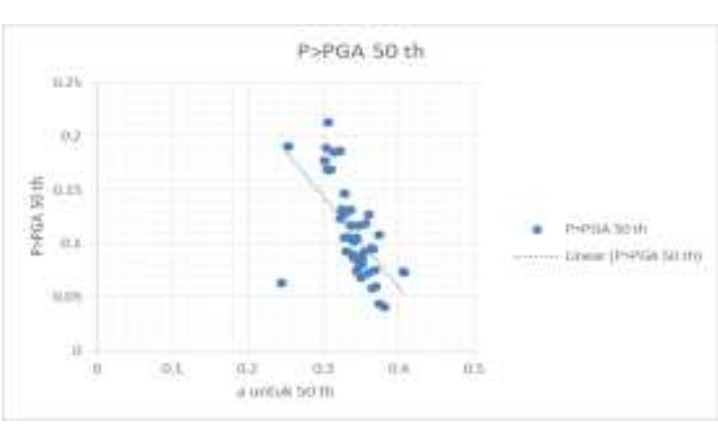

Fig. 6: The PGA value for 50 year

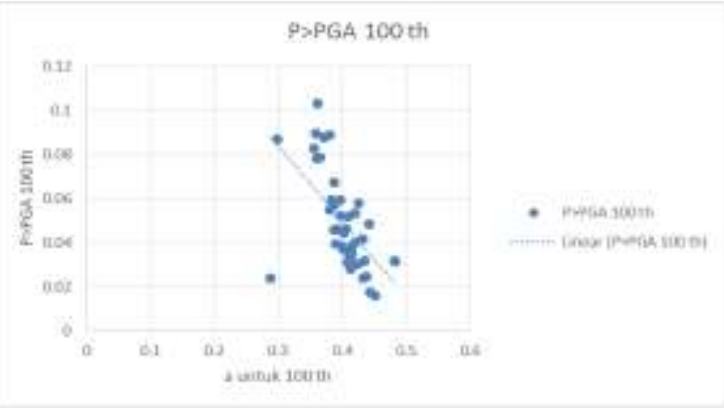

Fig. 7: The PGA value for 100 years

Based on Fig. 6 and 7 shows that the visualization of PGA for the next 50 and 100 years by using a scatter plot graph. The graph uses a probability value as the y-axis value and the value of ground motion acceleration (a) as $\mathrm{x}$-axis. In PGA for 100 years, it can be seen that the highest value for the greatest probability is exceeded by the value of 0.103 in District Pesanggrahan with ground motion acceleration value 0.361 gals. It is also similar to that presented in Figure 6. On the value of PGA for the next 50 years Pesanggrahan Sub-district has the highest value for the probability of exceeding. So, it can be concluded that the greater the value of the acceleration of ground motion, then the smaller the probability value is exceeded is generated.

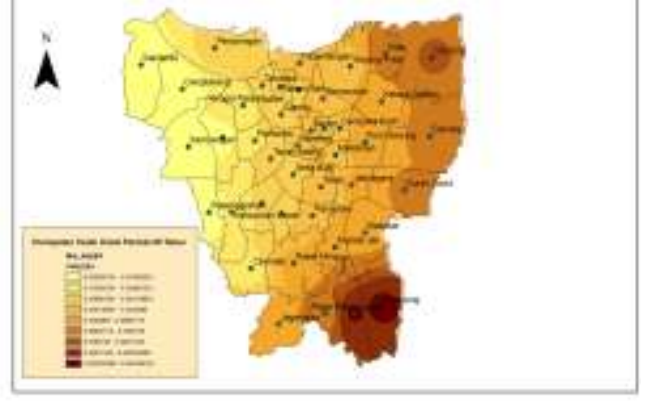

Fig. 8: The PGA value for year 50 on mapping

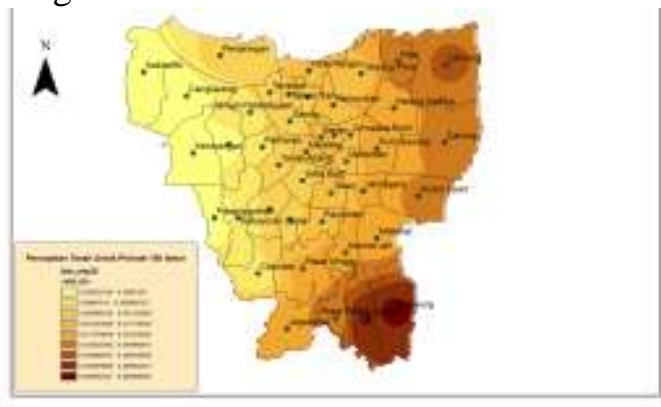

Fig. 9: The PGA value for year 100 on mapping

In Fig. 8 and 9, shows the result of visualization using software Geoda to present the value of PGA for the next 50 years and 100 years in mapping. By using ground motion acceleration data generated for a period of 50 years from now obtained some categories for areas to high ground motion acceleration when the sub-district hit by a magnitude above $5 \mathrm{SR}$. With light brown color illustrates the value of ground motion acceleration is relatively small in units of gals to dark brown or dark for ground motion acceleration is relatively large. It can be seen that the direction of the North the point of the review (sub-districts in Jakarta), the smaller the value of the acceleration motion of the land. However, further to the South on point of the review, the greater the acceleration of ground motion generated. It is very dangerous when the quake shook the area in. A region with a high acceleration of ground motion which obtained the administrative area of East Jakarta (Cipayung and Ciracas) and which has a small ground motion acceleration contained in the administrative area of West Jakarta.

On Fig 9, the map has a picture is nearly equal to describing the area that has the acceleration of ground motion are small and large. However, it is distinguished by the value of the acceleration of ground motion that appears. It can be seen that the range for the map PGA 50 years less than the PGA map for 100 years. It can be concluded that the longer the return period prediction of ground motion acceleration that greater the acceleration 
of ground motion that will be generated. In other words, Jakarta from year to year continues to increase acceleration of ground motion when the earthquake.

\section{Conclusion}

The value of acceleration of ground motion in Jakarta obtained from 44 points in each district's review into the high category on a scale of Marcelli. Because of the 44 point review measuring for 50 years and 100 years, Jakarta has a value above 0.2 gals, but for every existing probabilities of every 44 point review it exceeded a little after calculated using the equation of $\mathrm{Li}$ et al (2010). With the acquisition of these figures, Jakarta must be resilient to the foundation that can withstand ground acceleration above 0.2 gals when Jakarta was rocked by an earthquake.

\section{References}

[1] Asian Disaster Reduction Center (ADRC), Total Disaster Risk Management - Good Practices. Kobe, Japan, 2005, Japan.

[2] Asrurifak M, Map of response spectra Indonesia to plan Based Earthquake Resistant Buildings Earthquake Source 3-Dimensional In Probability Analysis, Doctoral Dissertation, Department of Civil Engineering, 2010, Bandung Institute of Technology.

[3] Campbell, K.W., and Bozorgnia, Y., Ground motion model for the geometric mean horizontal component of PGA, PGV, PGD and 5\% damped linear elastic response spectra for periods ranging from 0.01 to $10.0 \mathrm{~s}$, 2008.Earthquake Spectra, v. 24, no. 1.

https://doi.org/10.1193/1.2857546

[4] David M. Boore, William B. Joyner, and Thomas E. Fumal, Equations for Estimating Horizontal Response Spectra and Peak Acceleration from Western North American Earthquakes: A Summary of recent Work, Seismological Research Letters, 1997, Vol. 68, No. 1, 128-153. https://doi.org/10.1785/gssrl.68.1.128

[5] Gutenberg, B., Richter, CF, Frequency of Earthquakes in California Bulletin of the Seismological Society of America, 1994, America.

[6] Idriss, I.M, Evaluating Seismic Risk Engineering Practice, Proceedings of the 11th International Conference on Soil Mechanics and Foundation Engineering, 1985, San Francisco, Vol. 1, 255-320.

[7] Irsyam, M., Subki B., Himawan A., Suntoko H, Analysis of seismicity for the Muria Peninsula, Proceedings of the National Conference on Earthquake Engineering, Earthquake Engineering Development Utilization Improvements in the Framework Regulation and Increased Public Awareness Against Earthquake in Indonesia, 1999, pg. VI- 9-VI-20.

[8] Li, Lian-Fa., Wang, Jin-Feng., Leung, Hareton. 2010. Using Spatial Analysis and Bayesian Network to Model the Vulnerability and Make Insurance Pricing of Catastrophic Risk. International Journal of Geographical Information Science. https://doi.org/10.1080/13658816.2010.510473

[9] McGuire, R.K. 1976. EQRISK (Evaluation of Site for Earthquake Risk) User's Manual. United State Department of Interior Geological Survey.

[10] McGuire, R.K. 2001. Deterministic vs. Probabilistic Earthquake Hazards and Risk, Risk Engineering Inc. Publication Paper.

[11] Oktariadi, O. 2012. Peak Ground Acceleration Studies of the Indonesia Earthquake Zone Maps in the Special Region of Yogyakarta. Undergraduate Theses. Civil Engineering. Sepuluh Nopember Insitute of Technology.

[12] Purcaru, G. and Berckhemer, H. 1978. A magnitude scale for very large earthquakes. Tectonophysics, 49, 189-198. https://doi.org/10.1016/0040-1951(78)90177-4

[13] Putra, Riski Purwana, Maximum Acceleration Study Earthquake Earthquakes Map Indonesia in Yogyakarta. Thesis, Department of Civil Engineering, 2010, Institute of Technology.

[14] R. R. Youngs, S. -J. Chiou, W. J. Silva and J. R. Humphrey, Strong Ground Motion Attenuation Relationships for Seduction Zone Earthquakes, Seismological Research Letters, 1997,Vol. 68, No. 1, 58-73.

https://doi.org/10.1785/gssrl.68.1.58

[15] Septianusa, Maulina S, Atina Ahdika, Deterministic and Probabilistic Seismic Hazard Risk Analysis in Bantul Regency. Advances on Science and Technology. Proceedings of SESEE, 2015, (Statistical Methods in Engineering, Science, Economy, and Education) 2015. 